\title{
US to EU: Please, pass the maize
}

High-level US officials, including President Clinton, Secretary of State Madeleine Albright, and Secretary of Agriculture Dan Glickman, are urging officials of the European Union (EU) to ease several international trade matters, particularly those affecting biotechnology

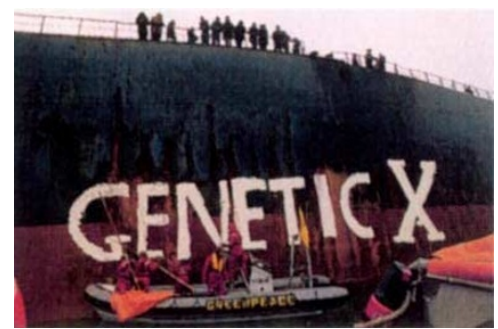

Greenpeace blocked soya imports; the EC is blocking maize. food and agricultural products. Following a series of strongly worded letters from US to European Commission (EC; Brussels, Belgium) officials, these matters were also under consideration during the December summit talks involving Clinton, other top officials, and EC President Jacques Santer. These issues were raised forcefully by officials who expressed concerns about potential trade disruptions.

Both Clinton and Albright are including biotechnology-related, agricultural-trade issues on their respective agendas-apparently the first time such matters have gotten these top-level visibility. Although officials say Albright is "expressing frustration over the current situation," referring to stalled reviews of biotechnology products in Europe, these issues fall more squarely in Secretary Glickman's bailiwick.

In preparation for the summit and more detailed negotiations that will continue early this year, Glickman recently sent Franz Fischler, the European Agriculture Commissioner, and other members of the $\mathrm{EC}$ a detailed and strongly worded letter. In it Glickman expressed "grave concern" over long-delayed regulations governing biotechnology agricultural and food products, and demanding that the EC fully implement a workable approval process. He also insists that several genetically engineered corn products move to final review in a "timely manner," and "that no steps are taken to disrupt imports of US maize in the interim."

EC regulations requiring that foods with genetically modified ingredients took effect last November, but EC officials still have not clarified what ingredients will trigger the need for a label and what those labels will say (Nature Biotechnology 15:1331, 1997). Meanwhile, although officials have approved at least one genetically engineered variety of corn, the EC regulatory process for approving such whole crops seems to have come to a halt while the regulatory system itself is being reconfigured.
In a move that dazzles with brinkmanship, the European Commission (EC; Brusseis) has put yet another barrier in front of the progress of food-related biotechnology products to the market and turned up the heat on a trade war with the US. It is the turn of the Scientific Committee on Plants of the newest division of the EC, DGXXIV-the Directorate General for Consumer Policy and Consumer Health Protection-to examine the dossiers for three recombinant maize products which are awaiting marketing approval within the European Union (EU; Brussels). The committee was formed only on November 5, 1997 and, as of the mid-December, had only held one formative meeting. Industry representatives feel that the new committee has been set up "without any process" and without any operating parameters: "There aren't any rules," said one. "They [the EC] are making them up as they go along." Members of the new committee could not say whether any of the maize products would be on the agenda of its next meeting or indeed when that next meeting would be.

Seven recombinant maize products were produced commercially in North America
Because these delays are directly affecting several US agricultural products, Secretary Glickman argues that further dalliance on the part of EC in the biotechnology arena will "risk fundamental damage to agricultural trade relations between the United States and the European

seem to have encountered any technical barriers, there were no approvals by early December. EC officials have forwarded the discussion to the recently formed Scientific Committee on Plants of the European Commission's Directorate-General XXIV on Consumer Policy and Consumer Health Protection (see below, "Maize faces new hurdle in EU"). "It has become apparent ... that the rules of the game are once again changing," Glickman contends. "The goal is being pushed further and further back even as these products advance through the approval process."

With top US officials taking up the cudgel Union." Specifically, he points to four genetically engineered varieties of corn that have been languishing within the $\mathrm{EU}$ review process for about two years.

The commercial sponsors of those products "earnestly followed the known conditions for approval," Glickman notes. Moreover, "based on their good faith compliance with established procedures and evolving labeling requirements," the sponsors "had every reason to anticipate" that, by now, the products would have reached the final stages of review or been approved.

However, although the products do not for biotechnology agricultural products, Glickman's complaints may turn into stronger actions if the US Trade Office begins like restraint of trade and decides to enter the fray, insiders are suggesting. US exports of corn and corn products amount to $\$ 1$ billion annually, one official points out. US officials wanted EU officials to "go back knowing there are concerns and that they should expedite the decision making.

Jeffrey L. Fox to see $\mathrm{EC}$ foot-dragging as something more

\section{Maize faces new hurdle in EU}

during the last growing season but only one of them-Novartis' (Basel, Switzerland) insect-resistant and herbicide tolerant variety-has been approved within Europe. Another three products-including one each from Dekalb Genetics (Dekalb, IL) and Pioneer Hi-bred (Des Moines, IA)-are unlikely to be approved in Europe soon and have accordingly been segregated by North American growers. There are, however, three strains of corn that have become entangled in the Brussels bureaucratic web. They are another insect-resistant, herbicide-tolerant strain from Novartis (this one was developed by the Sandoz side of the company); the P25 Liberty herbicide-tolerant corn from AgrEvo (Frankfurt and Berlin), and an insect-resistant variety from Monsanto (St Louis, MO).

Under procedures defined in the 1990 European directive on deliberate release, which apply to recombinant plants, member states have 60 days in which to comment or register objections to products under review. Taking those views into account (or not), the EC formulates a "proposal" (recommending the products, or otherwise) and forwards it to the "Article 21 committee," the group of rep- 